FACTA UNIVERSITATIS

Series: Philosophy, Sociology, Psychology and History Vol. 17, N 1, 2018, pp. 55 - 70

https://doi.org/10.22190/FUPSPH1801055D

Review Paper

\title{
THE CONCEPT OF ECOLOGICAL SUSTAINABILITY AND A BRIEF OVERVIEW OF THE ATTEMPTS OF ITS IMPLEMENTATION IN SERBIA
}

\author{
UDC 502.1
}

\section{Jelena Dinić, Irena Tasković}

University of Niš, Faculty of Philosophy, Serbia

\begin{abstract}
The basis of the advancement of contemporary society comprises the development of science and technology, intensified by the globalization processes. The tendency to progress further and produce more in order to improve the living conditions of people has also led to certain adverse consequences reflected in the ecological crisis, that is, the disturbance of the ecological balance. In an effort to come up with a solution, the model of sustainable development was created on the basis of harmonizing the economic needs with the preservation of the ecological balance both at the global and the local level. A healthy and high-quality living environment is not only the basic condition for economic wealth, but clean air, healthy water and healthy soil and food also present the fundamental preconditions for the good health of people.

The concept of sustainable development is a relatively new notion, particularly in Serbia. However, it has neither been developed nor implemented sufficiently in our country. The reasons behind this are numerous, among which the unfavourable economic situation certainly occupies an important position, along with the fact that the concept of sustainable development still does not represent a widely accepted development paradigm in Serbia. For Serbia, as a developing country, it is of particular importance to preserve its ecological balance and ensure sustainable development, which is possible, among other things, by cooperating internationally in the sphere of environmental protection
\end{abstract}

Key words: living environment, ecological crisis, sustainable development, Serbia.

Received September 21, 2017 / Accepted May 22, 2018

Corresponding author: Jelena Dinić

University of Niš, Faculty of Philosophy, Ćirila i Metodija 2, 18000 Niš, Serbia

E-mail: jelendzi@hotmail.com 


\title{
1. INTRODUCTION
}

\author{
"As the ocean 'waves,' the universe 'peoples.' \\ Every individual is an expression of the whole realm of nature, \\ a unique action of the total universe" \\ (Alan Watts 1966, according to Đurić 1998)
}

Globalization is a phenomenon of the modern era. ${ }^{1}$ It is a global process that took place at the end of the $20^{\text {th }}$ and the beginning of the $21^{\text {st }}$ century. The basis of globalization is the creation of a unified economic and political space of global dimensions and it can be understood as the merger of national economies into a world economy. This implies the liberalization of international economic relations, the existence of certain standards, both in the economic and the legal system, and the pronounced importance of international institutions in the assurance of an unhindered functioning of the new concept of world economy (Crafts 2004). Therefore, it is the case of economic integration and cooperation of global dimensions, and it relates to tearing down the obstacles that stood in the path of trading goods, services, movement of capital and people, i.e. the workforce (Dinić 2011). Money and profit have gained enormous and real power that is possessed by transnational banks and corporate multinational societies. Such a "globalized economy" does not acknowledge state borders and is led by the logic of maximum exploitation of all potentials with the aim of generating as much profit as possible (Karlić 2008).

It is a fact that science and technology comprise the basis of global integration, which leads to the technological, economic and cultural connection between individual societies and the development of the relations of interdependence. However, the application of scientific knowledge and technology also compromises the balance of the biosphere, causes environmental problems and leads to an ecological crisis. Today, these processes encompass the entire world, and the discourse on the living environment and ecological problems can no longer be limited to certain areas but has to be expanded to the global level (Miltojević 2004a), thus gaining more and more importance every day. Therefore, living within environmental boundaries is one of the central principles of sustainable development and the topic of this paper.

\section{THE ECOLOGICAL CRISIS AND THE CONTEMPORARY WORLD}

The economic needs of contemporary society impose a constant tendency for evergreater progress and mass production so as to ensure the better material situation of people. However, apart from improving the living conditions of people, this huge technological advancement has also had negative effects on the living environment (Romančikova and Mikocziova 2011). Due to the excessive influence of the human society on the environment, the ecological balance, necessary for the survival and further development of humanity, has been disturbed. This disturbance is simultaneously accompanied by the industrial development of the economically most developed countries (Nešković 2009).

\footnotetext{
${ }^{1}$ The opinion that globalization is the phenomenon of the modern era is often found debatable, which is further corroborated by the existence of world religions and trade routes in the Middle Ages (for more details see: Pečujlić 2005).
} 
People have upset the ecological balance, the mutual and harmonized connection within the living world, with their activities aimed at improving their living conditions. By endangering the natural environment, people have endangered the integrity of their own survival at the same time (Bjelajac, Dašić, Spasović 2011).

According to Nešković (2009), the ecological crisis is most often displayed on three levels. The first and the lowest level of environmental pollution is the one where the ecological balance is disturbed, yet the disturbance is not that great for nature to be unable to regenerate itself and return to the normal state in due time. The second level relates to the natural environment being endangered to the extent where the ability of the ecosystem and the biosphere to self-regulate has been reduced significantly; thus the re-establishment of the balance is not possible without human activity. The third level relates to the destruction of the natural environment. This is the final stage in the ecological crisis where the pollution and the destruction of nature are such that the regeneration of certain ecosystems is almost impossible or implies huge human effort over a long period of time, without any guarantee of a positive outcome.

The living environment is global, and it functions as a closed ecosystem, which is why no ecological problem can be observed as exclusively local. The majority of ecological problems, such as declines in biodiversity, pollution, reduction of arable land, exploitation of natural resources and climate change, increase with the intensification of globalization (Ehrenfeld 2003; Pajvančić-Cizelj 2015). The major threats to the ecological balance at the global level can be found in the demographic expansion or the demographic boom, the exploitation of natural resources (particularly the non-renewable ones), the problem of energy emitted by modern technological achievements, the abuse of the findings of biological, chemical and medical sciences, the uncontrollable deforestation that reduces the amount of oxygen on the planet, global warming resulting in the greenhouse effect, water management problems, the extinction of birds and animals, and pollution of nature as a universal problem (Ehrenfeld 2003; Vranješ 2009; Biočanin 2011).

Observed in this manner, it is evident that a local threat can have global dimensions and consequences. There is not a single country, region or continent that cannot be affected by a certain ecological problem. For example, the greenhouse effect attacks both Europe and the USA, as well as all the other countries on the planet. This can also be said of nuclear radiation, or a possible use of any type of weapon of mass destruction. Therefore, the resolution of global ecological problems requires the action of all, i.e. a global action (Vranješ 2009).

However, the territorial observation of globalization shows that apart from the economic, the world also suffers from the ecological inequality. Namely, nowadays, when the results of the implementation of global strategic plans are more than obvious, it is evident that the greatest price has been paid, is being paid, and will be paid by developing countries. Developed countries, which first started the globalization process, are not affected by the losses incurred by the economy and society of developing countries (Waller-Hunter, Jones 2002). Grasping the importance of the vicinity of raw materials, production and market, their manufacturing is mainly dislocated across various countries with cheap labour and lower costs. This comfort can only be afforded by developed countries (Mićunović, Novaković i Stefanović 2015). On the other hand, developing countries cannot afford such comfort, and the ones that have decided to outsource their production elsewhere are most of the time left without work, which eventually leads to an increasing dissatisfaction and social unrest. The economic inequality further conditions the inequality in the opportunity to 
invest resources into environmental protection. This opportunity thus drastically differs from country to country, in line with their economic power (Mićunović, Novaković i Stefanović 2015). In that sense, the eternal debate between globalists and antiglobalists on the ultimate consequences of globalization gains importance all the time.

Inequalities in the domain of ecological globalization are first expressed in the fact that the developed parts of the world participate increasingly in the creation of ecological problems but suffer their consequence to a lesser extent. For example, water scarcity now affects almost 1.3 billion people, the majority of which live in undeveloped countries (Monaghan 2011; Pajvančić-Cizelj 2015). Water, on the other hand, is becoming a general good, the so-called "virtual water", which circulates increasingly at the global level, where people often use water that comes from the other side of the world not being aware of its scarcity (Pajvančić-Cizelj 2015). ${ }^{2}$ Bearing in mind the inequalities that accompany globalization, it is not difficult to conclude that the establishment of any kind of global standard oriented towards the preservation of the living environment that could be met by all countries is almost impossible. Then again, such a standard is inevitable since this is no longer merely the case of environmental protection but the issue of the very survival of the human species on Earth (Mićunović, Novaković i Stefanović 2015).

\section{THE AWAKENING OF ENVIRONMENTAL AWARENESS IN THE WORLD AND THE INCEPTION OF THE IDEA OF SUSTAINABLE DEVELOPMENT}

Global society faces numerous global problems, among which an important place is occupied by the disturbance of the ecological balance on the planet Earth to such an extent that one could speak of a global ecological crisis. The devastation and degradation of the natural environment has reached enormous dimensions (Waller-Hunter, Jones 2002; Nešković 2009; Martens and Raza 2010). However, at the same time, the awareness of these ecological problems has been raised, which has led to the awakening of environmental awareness and the formation of the environmental culture (Miltojević 2004a).

The development of environmental awareness has further developed the tendency to find solutions to the ecological crisis, thus the idea of sustainable development has been born, based on the harmonization of economic needs with the preservation of the ecological balance at the global, but also the local level (Pavlović 2011). Drljača (2012) states that sustainable development and the very term "sustainability" were first mentioned in 1968 at the gathering known as the Club of Rome. Within its six reports, based on substantial scientific analyses, the Club of Rome issued an appeal to world leaders to change the way in which people treated the planet Earth. The reports showed that if the trends in the population growth, industrialization, food production and exploitation of natural resources continued without change, the growth limits on this planet would be exceeded, resulting in the eventual decline in population and industrial capabilities. At the same time, at the international level, the UN declaration on the human environment was adopted in Stockholm in 1972, stating that scientific and technological achievements should be used for the improvement of the economic and social development with the aim of discovering

\footnotetext{
${ }^{2}$ In that sense, it is pointed out that, for example, 140 litres of water are necessary to grow enough coffee beans for a single cup of this beverage. Thus, water is consumed in one place, and that cup of coffee in another (in more detail: Pajvančić-Cizelj 2015).
} 
and limiting all of the hazards that could affect the environment (Miltojevic 2004b). In that vein, the 1987 report by the World Commission on Environment and Development (WCED, 1987), as part of the "Our Common Future" report, developed the model of sustainable development. This form of development represents a new social relationship towards the environment and natural resources, and it implies the idea of the existing responsibility towards the present and future generations (Miltojević 2004a; Romančikova and Mikocziova 2011). The main guidelines of sustainable development are the insistence on providing future generations with at least equally good living conditions as are present today, and the attempt to improve the situation in developing countries, regardless of the introduction of more stringent standards in economy with the aim of resolving ecological problems (Miltojević 2004b; Nadić 2011). The report also proposed the setting up of the UN programme on sustainable development and an international conference on environment and development (Štrbac, Vuković, Voza i Sokić 2012).

The UN Conference on the Human Environment in Rio de Janeiro in 1992 saw the adoption of the Declaration on Environment and Development that promoted the concept of sustainable development (Nešković 2009), while the United Nations Resolution known as the Millennium Declaration was adopted in September 2000 with its main development goals. The Millennium Development Goals comprised eight objectives agreed upon by all 191 members of the United Nations in an attempt to achieve them by 2015. The goals were related to the eradication of poverty and hunger in the world, fundamental education for all girls and boys across the globe, reduction in child mortality, improvement of the position of women in the world, the fight against HIV and AIDS and other diseases on the global scale, assurance of environmental sustainability and development of global partnerships for the purpose of achieving these goals. The Millennium Goals raised awareness of the important aspects of development and mobilized governments worldwide to pay more attention both to the social welfare and health of people and the environment itself.

In September 2016, the General Assembly of the UN adopted a new global development agenda - the 2030 Agenda for Sustainable Development, together with a new set of global goals, which represent the continuation of the Millennium Goals and strive to achieve what the latter did not manage to. Compared with the Millennium Declaration, the Agenda represents a much more comprehensive programme that contains 17 universal goals of sustainable development, whose successful implementation will require the involvement of all available resources, both at the domestic and the international level. Namely, contrary to the Millennium Development Goals that were directed towards developing countries, the Agenda is a global agreement to determine a universal, all-encompassing action programme for all countries. Taking into consideration the level of development, national context and possibilities, all countries will have to contribute to the cause, and it is precisely the national responsibility and the responsibility towards one's own citizens that will be of crucial importance for the success of this programme (Pavić-Rogošić 2015).

It can be said that sustainable development is a relatively new concept, yet it today occupies a central position in the programmes of many governments, companies, educational institutions and non-governmental organizations across the world. This concept has been introduced with the aim of overcoming the deficiencies of previous development models, above all the neglect of the issue of environmental protection, and it is thus characterized by the tendency to harmonize the economic, social and ecological components so as to preserve the natural wealth of the planet Earth for future generations (Štrbac, Vuković, Voza i Sokić 2012). Nešković (2009) believes that the essence of the sustainable development model lies 
in the need to harmonize economic activities with economic capabilities, i.e. to preserve the ecological balance and align production with natural constraints, which means limiting the exploitation of natural resources.

Pavlović (2011) emphasizes that one can differentiate between three dimensions of the meaning of the concept of sustainability. The first relates to the natural ecological sustainability, i.e. the ability of self-renewal of complex ecosystems that includes both the living and the non-living world. The second relates to the sustainability of renewable resources in the sense of their balanced exploitation, while the third dimension relates to a more rational use of non-renewable resources and their replacement with renewable sources. Today, the term sustainability mainly relates to the last of these dimensions.

According to the principle of sustainable development, it is necessary to achieve economic growth with at first reduced and later completely discontinued exploitation of natural resources and degradation of the human environment. This should, in fact, be a type of development that would ensure the satisfaction of the current generations' needs, without jeopardizing the possibility of satisfying the future generations' needs as well (Žužek 2009). Such a social development can contribute to the resolution of ecological problems and improvement of the quality of life, particularly through the strengthening of supranational institutions in the sphere of environmental protection (Miltojević 2004a). Its essence lies in the care for future generations and orientation towards the future.

The concept of sustainability is today widely accepted as the condition for the survival and progress of humanity. Pešić (2002) talks about certain reasons for its creation and development in general, thus emphasizing that there exist "strong moral reasons for the present generation to leave nothing less to its posterity than the equal chances for development as they enjoy now. This means that planet Earth, with all its potentials, must not be degraded by the existing populace", as well as that the right of the current generation to exploit natural resources and the environment must not endanger that same right for future generations. The second group of reasons for sustainable development are ecological in nature. The author explains that if nature represents a value in itself, i.e. if the preservation of biodiversity or the reserves of natural resources is justified by the attitude that humans are only a part of nature, then any form of economic activity that compromises the diversity of the living world, or the wealth of resources, is unacceptable. The third reason behind the concept of sustainability is the economic argument that sustainable development is more efficient. In other words, not acknowledging the concept of sustainability leads to inefficient economic development, in the sense of increasing resource and energy losses, i.e. the tendency to cause long-term deterioration on the global scale.

The model of sustainable development is grounded in three major premises, and these are the understanding that all people have the right to live a healthy life in accordance with nature, that countries have a sovereign right to use natural resources, but in a way that does not endanger the living environment of other countries, and that international cooperation is inevitable in the effort to resolve ecological problems in the best possible manner (Miltojević 2004b; Martens and Raza 2010).

\footnotetext{
${ }^{3}$ The two most important international organizations that deal with environmental protection, and which act globally and have a legal and political capacity under the jurisdiction of the UN, are: UNEP and UNDP. The United Nations Environment Programme (UNEP) is a UN programme which aims at creating and strengthening partnerships for environmental protection and quality development at the global level. The seat of this organization is in Nairobi, Kenya, although it has its offices all around the world. The programme is led by the
} 
The model of sustainable development prioritizes the satisfaction of needs and the resolution of conflicts between economy and ecology, i.e. the harmonization of economic development with the possibilities and capacities of the biosphere. The improvement of the living conditions in a community, the strengthening of the relationship between economy, environment and society, can be achieved through sustainable economy, sustainable use of energy and sustainable industrial activities. Such an approach provides the basis for further development of the society, which implies not only increases in profit, but also the humanization of the working and living environment (Miltojević 2004b). In an effort to point to the importance of sustainable development as well as the need to introduce the world to these standpoints, and to transform ideas into actual efficient actions as soon as possible, the UN declared the period from 2005 to 2014 the Decade of Education for Sustainable Development (Vranješ 2009).

\section{Monitoring Sustainable DeVElopment}

To successfully manage sustainable development, both at the local and the global level, it is necessary to possess a high-quality system of data acquisition and analysis in the field of environmental protection and management of limited natural resources, as well as to assure a realistic picture of the data on pollution or resource scarcity (Janković-Milić, Jovanović i Krstić 2012). Sustainable development indicators provide information on how well we live, how resources are distributed, how efficiently they are used, what the current state is and what the consequences to the environment are, so that we can better understand the world around us (Milutunović 2010; Veljković 2011). They are our link to the world. They warn us of a problem before it becomes too grave and they help us understand what needs to be done in order to solve it (Bossel 1999).

Miltojević (2004b) emphasizes that sustainable development indicators are categorized into four groups. The first group comprises social indicators that point to social justice, health, education, residential conditions, safety and demographic changes. The second group consists of economic indicators that relate to economic structure, consumption and production. The third group encompasses institutional indicators that deal with introducing the environment and development in decision making, potential scientific resources to achieve sustainable development, national mechanisms and international cooperation. The fourth group is made up of environmental indicators related to atmosphere, soil, oceans, seas, water and biodiversity. ${ }^{4}$

Executive Board, which reports to the General Assembly of the UN. Not one of the former Yugoslav republics currently have their representatives there. The United Nations Development Programme (UNDP) is a UN development programme directed towards connecting countries with the aim of their development and exchange of experiences, and for the purpose of achieving better living conditions. This programme has a global character and it includes 166 countries. The programme covers the following areas: democratic rule reduction in poverty, prevention of crises and renewal, environment and energy, and fight against HIV/AIDS. When it comes to the living environment, the organization deals with the following: sustainable development strategy, water management, sustainable energy, sustainable development of earth, biodiversity, chemical management and national policies and programmes of radiation hazards control (in more detail: Vranješ 2009).

${ }^{4}$ There are different methods of selecting sustainable development indicators. The following are mentioned in the literature: Three-ring circus model, Russian dolls model, Night-owl model (in more detail: Levett 1998; Wu, Liou, and $\mathrm{Su} 2014)$. 
Today, a number of composite indicators are used to monitor sustainable development, and these indicators are created so as to obtain a clearer picture of the interdependence of various development aspects at the international level (Veljković s.a.). To measure the performance of the living environment, the Environmental Sustainability Index (ESI) was first developed under the auspices of the UN and published by the World Economic Forum. ESI deals with how much countries are capable of environmental protection. The index encompasses natural resources, pollution levels, efforts in environmental management and abilities of a society to improve its ecological achievements (Esty, Levy, Srebotnjak, and de Sherbinin 2005). It is expressed on a scale from 0 to 100, where a higher ESI result indicates better environmental management. Due to the constraints of this index as a guideline of economic policy based on a large number of wide-scope indicators, the most recent report on it was published in $2005 .^{5}$

Since 2005, the Environmental Performance Index (EPI) has been used. Its value is also given on a scale from 0 to 100 , and it measures the total contribution of a country to the preservation of the environment, taking into account major global environmental problems as well as the ways in which certain countries deal with them. It focuses on a narrower set of environmental protection issues so as to yield more easily applicable and clearer results and facilitate the comparison between countries. This index allows for the identification of key areas in which the situation needs to be improved, in line with the practices of other countries that have achieved substantial results in those areas (Janković-Milić, Jovanović i Krstić 2012). ${ }^{6}$

Yet another indicator that deserves attention was developed by the Canadian economist William E. Rees and named the ecological footprint (Veljković s.a.). This sustainable development indicator shows the relationship between the existing natural resources and their consumption by human beings (water, soil, air, coal, crude oil, ores, etc.). It includes water, air, ores, soil, arable land, meadows, populated areas, fishing and forest areas necessary for the absorption of carbon dioxide not absorbed by the oceans. Almost every aspect of human activity, particularly today in the globalized world, affects the planet. Everything, from the type of diet, through transport, to waste management has a smaller or larger ecological footprint. The greater the consumption of natural resources, the larger the footprint made by people on nature. Resources are being consumed at such an enormous speed that nature is not capable of making up for the lost natural resources at the same speed (Muradian 2004; Lukas, Kay, and Offermans 2017). ${ }^{7}$

The inequality characteristic of the contemporary world is also pronounced in this case. The ecological footprint is unevenly distributed, since developed countries use more natural

\footnotetext{
${ }^{5}$ Out of 146 countries in 2005, according to ESI, the best positioned were Finland, Norway, Uruguay, Sweden, Iceland. Serbia and Montenegro were ranked $89^{\text {th }}$ that year (2005 Environmental Sustainability Index Report available at: http://sedac.ciesin.columbia.edu/es/esi/ESI2005.pdf).

${ }^{6}$ According to the data from 2014, out of 178 countries the Republic of Serbia was ranked $31^{\text {st }}$ according to EPI, while Switzerland, Luxembourg, and Australia occupied the first three places, respectively (in more detail: Hsu et al. 2014)

${ }^{7}$ It is believed that the carbon that comes from the combustion of fossil fuels has been the main culprit of the increasing ecological footprint in the last fifty years. The literature states that the greatest increase in trafficinduced carbon dioxide is expected in Eastern and Central Europe, the former USSR countries, China, Central Asia and other developing countries (in more detail: Van Veen-Groot, and Nijkamp 1999).
} 
resources than they require while some of the poorest countries in the world barely have enough for their basic needs (Global Footprint Network 2016). ${ }^{8}$

\section{The ECOSYSTEM OF SERBIA AND ATTEMPTS AT SUSTAINABLE DEVELOPMENT}

Environmental protection and improvement are among the main priorities on all continents. Not only is the healthy and high-quality environment a basic condition for economic wealth, but clean air, healthy water and healthy soil and food also present fundamental preconditions for the good health of people (Kanjevac Milovanović, Milivojević i Kokić Arsić 2008).

The only legally defined and binding evaluation of the pollution level in the Republic of Serbia is the air quality assessment based on the exceeding of boundary and tolerant values of pollutant concentrations (Popović 2015). The data show that during 2014 the air quality in the Vojvodina region, the cities of Novi Sad, Niš, Pančevo and Kosjerić, was of the $1^{\text {st }}$ category, clean or slightly polluted air, and that no boundary values of any pollutant concentrations were exceeded. In Belgrade, on the other hand, during 2014 the air was of the $2^{\text {nd }}$ category, moderately polluted air, while in the cities of Bor, Užice, Smederevo and Valjevo the air was of the $3^{\text {rd }}$ category during 2014, meaning highly polluted air.

The main sources of air pollution are the energy and transport sector and industrial plants (UN 2007). When it comes to Serbia, the equipment for exhaust gases treatment in power plants is inadequate, and the combination of inefficient combustion and inadequate maintenance results in high levels of exhaust gases. The causes of pollution in the industrial sector are similar to the exhaust gas emitters in the energy sector: outdated technologies, lack of flue gases treatment or low efficiency of filters, poor quality of raw materials and low energy efficiency, as well as inadequate functioning and maintenance.

One of the most important causes of environmental pollution is the inappropriate sewerage infrastructure, i.e. inadequate wastewater collection and treatment. The sewerage system covers $48 \%$ of the population of the Republic of Serbia, but there are huge variations in the coverage between districts, as well as between the urban and rural population. Furthermore, the main sources of water pollution are the untreated industrial and municipal wastewater, agricultural discharge, landfill discharge as well as pollution related to the water transport and thermal power plants. The discharge of industrial wastewater in Serbia is most concentrated in the Sava river basin, which takes in around $80 \%$ of industrial waste (UN 2007).

Only 28 cities have plants for wastewater treatment. The largest cities, such as Belgrade, Novi Sad, and Niš, release their wastewater untreated into the rivers. Moreover, certain plants are abandoned, partially dysfunctional or provide only mechanical treatment. The loss of water in the water supply system in Serbia expressed in percentages in the period from 2005 to 2013 generally had a negative (increasing) trend. Losses of over $50 \%$ were to be found in the Kolubara (51\%) and Zaječar district (53\%). Particularly significant is the data on the size of losses in the Belgrade water supply system of around $27 \%$, whose

\footnotetext{
${ }^{8}$ According to the data obtained from SEPA, the Serbian ecological footprint is 2.33 , which is lower than the one of the neighbouring countries, with a deficit amounting to -0.95 global hectares per citizen. When the ecological footprint and the biocapacity are compared at the regional plan, a clear picture is obtained in the production, import and export of certain countries and the wealth of their ecosystem. Bulgaria (EFp=4.07) has the largest ecological footprint (EFp) in the region, followed by Croatia $(\mathrm{EFp}=3.75)$ and Bosnia $(\mathrm{EFp}=2.75)$ (in more detail: Veljković s.a).
} 
reduction by only $10 \%$ annually would provide enough water to meet the needs of the city of Kragujevac (Veljković 2014).

In the case of soil, according to the Environmental Protection Agency (Government of RS 2015), in 2013 on the territory of the Republic of Serbia, 422 locations were identified as potentially contaminated. Urban areas in comparison to rural ones are more often subject to the anthropogenic influence due to higher population density, traffic intensity, vicinity of industry, etc. The examination of soil quality on the territory of the city of Belgrade in 2013 (Government RS 2015) showed that, according to certain parameters, the examined locations could be categorized as potentially polluted, while only a small percentage (3\%) as alarmingly polluted on the basis of the total content of nickel (Subotica, Smederevo - where the nickel content exceeded the boundary value in $100 \%$ of the samples). In the cities of Požarevac, Kragujevac, Novi Sad and Novi Pazar the results showed that, according to certain parameters, the examined locations could be categorized as potentially polluted (RZS 2015).

On the other hand, the geographical position of the country, the variety of climate conditions and the situation in habitats, create a rich biodiversity in forests and enable the presence of a number of different types of trees and plants. Pursuant to the Law on Environmental Protection (Official gazette RS 36/2009, 88/2010 and 91/2010), the Ordinance on the proclamation and protection of strictly protected and protected species of wild plants, animals and fungi (Official gazette RS 5/2010 and 47/2011) encompasses 1760 strictly protected species of wild algae, plants, animals and fungi, and 853 protected species of wild animals, plants and fungi.

Forests and wooded areas cover $28 \%$ of the territory of Serbia, and this current surface is twice the size it was at the end of World War II (UN 2007). The diverse flora of Serbia includes a number of medicinal herbs, fruit, vegetables, industrial and decorative plants. All of them are used for various commercial and non-commercial purposes. There are around 700 species of medicinal and aromatic plants in the Serbian flora. The vast richness of habitats has allowed the co-existence of numerous plants and animals of different biology, origin, time of emergence, distribution and way of life on the territory of Serbia. The centres of floral diversity in Serbia are high mountain regions, canyons and gorges, steppes and sand dunes, swamps, fens and marshes, preserved forest communities and the like (Lakušić, Stevanović, Jančić i Lakušić 2010). Apart from the diverse flora, Serbia is also characterized by a very diverse fauna. The permanently protected animal species in our country include: bear, lynx, western capercaillie, black grouse, beaver, otter, steppe polecat, stoat, weasel, rock partridge, hazel grouse and others (Official gazette RS 5/2010 and 47/2011).

The formulation of the National Sustainable Development Strategy of the Republic of Serbia began in 2005, and the Strategy was adopted in May 2008 with defined priorities and principles as a mid-term plan for the period from 2008 to 2017. The solutions proposed by the Strategy are harmonized with the European integration, the EU Sustainable Development Strategy, the UN Millennium Development Goals, and the National Millennium Development Goals in the Republic of Serbia, adopted by the Government of the Republic of Serbia in 2006.

The Serbian National Sustainable Development Strategy from 2008 (Official gazette RS 55/05, 71/05-correction and 101/07) defines sustainable development as "targets-oriented, long-term (continuous), comprehensive and synergetic process with impacts on all aspects of life (economic, social, environmental and institutional) at all levels. The long-term concept of sustainable development implies continued economic growth, but such growth 
that brings with it not only economic efficiency and technological progress, but also a higher share of cleaner technologies and innovation in the society as a whole and corporate social responsibility, enabling poverty reduction, long-term better use of resources, improved health and quality of life and pollution reduced to the carrying capacity of the environment, prevention of future pollution and preservation of bio-diversity".

Some of the main principles of the Strategy are the integration of the environmental issue into other political sectors, the preservation of the natural balance, the inclusion of costs related to the environment into the price of products, which would yield the full economic price to cover production expenses, the use and disposal of products during their entire "life" cycles, and sustainable production and consumption. The Action Plan for the implementation of the National Sustainable Development Strategy of the Republic of Serbia was adopted in March 2009 for the period from 2009 to 2017 (Official gazette RS 57/08), and it was later replaced by a new plan for the period from 2011 to 2017 (Official gazette RS31/10). The plans contain a detailed elaboration of the measures and activities intended for the implementation of the Strategy goals.

A sustainable development plan, defined in the Serbian National Strategy for 2017, reads: "Serbia in the year 2017 is an institutionally and economically developed country, with adequate infrastructure, harmonized with EU standards, a country with knowledgebased economy, efficient use of natural and man-made resources, higher efficiency and productivity, rich in human capital, with a preserved environment, historical and cultural heritage, a state with private-public partnership, offering equal opportunities for all citizens" (Official gazette RS 55/05, 71/05-correction and 101/07). The national priorities whose achievement should have led to the fulfilment of the sustainable development vision ending in 2017 are EU membership, development of a competitive market economy and balanced economic growth, development and education of human resources, development of infrastructure and balanced regional development, and protection and promotion of the environment and rational use of natural resources.

Today, in 2017, we can conclude that, although undoubtedly certain progress has been made in these last ten years, the vision has not been fulfilled in its entirety. Serbia now faces great problems and challenges in all spheres - social, economic, scientific, educational, legislative, institutional, environmental. Unfortunately, the concept of sustainable development has not been sufficiently developed or implemented in our country. The reasons for such a state of things are numerous, among which one should certainly mention the unfavourable economic situation and stagnation that lead to various budget restraints. Veljković (s.a.) also emphasizes that the several year-long policy of neglecting industrial and agricultural production, along with the policy of importing mass consumption goods, has categorized Serbia within the zone of non-European countries with regard to the quality of life.

Among the possible obstacles for the establishment of sustainable development is the fact that sustainable development still does not represent a widely accepted development paradigm in Serbia, which is an aspect that needs to be worked on. As Miltojević (2004a) states, the acceptance of new principles of environmental ethics would simultaneously open the possibility of observing development in line with real conditions, which would contribute to both cultural and biological diversity.

Sustainable development is multisectoral in its nature and it requires mutual harmonization and cooperation at all levels. Therefore, the responsibility is on the elites that rule at the state and local level to accept and apply the national sustainable development strategy not only as a 
plan with a determined implementation deadline, but also as a plan whose implementation is a never-ending process, which includes the constant adjustment of the existing sectoral and local strategies both to the necessities imposed by the process of globalization and the natural processes such as climate change (Veljković s.a.). To ensure an efficient national strategy it is necessary to view the real picture of its possibilities in relation to available resources and the real picture of the relationship with the environment (Mićunović, Novaković i Stefanović 2015).

\section{CONCLUSION}

The living environment is a term that implies "natural surroundings: air, water, soil, animal and plant world; phenomena and actions: climate, ionizing and non-ionizing radiation, noise and vibration; the man-made environment: cities and other settlements, infrastructural, industrial and other buildings, including the historical and cultural heritage" (Bjelajac, Dašić i Spasović 2011). The tendency towards ever-increasing progress and production in order to improve living conditions has also resulted in adverse consequences, which are reflected in the ecological crisis, i.e. the disturbance of the ecological balance. The rapid growth of human activity since the industrial revolution has resulted in the consumption of vast amounts of resources and energy, consumed over a relatively short time. Mass consumption and a high level of production have a significant influence on the ecology of the Earth, exploitation of non-renewable resources and creation of ecological problems, which lead to air, water and soil pollution (Srebrenkoska, Jašić, Sokolović i Cvrk 2013).

However, the dominant opinion today is that nature has its ultimate limits within which humans have to act, and overstepping these limits endangers their own survival. It has been shown that humans do not rule nature, and that nature is not inexhaustible, thus the wrong valuation of the world around us leads to an imminent disturbance in the ecological balance and ensuing environmental problems (Miltojević 2004a). The ecological crisis represents the endangered stable functioning of both biosphere and society, which jeopardizes the existence of humans as both natural and social beings (Nešković 2009). Therefore, it is not by accident that environmental awareness has been developed (Miladinović 2012). The environmental issue has become the constituent part of political programmes in the majority of industrially developed countries. Still, the advocates of environmental protection often remonstrate that not much has been changed (Stojaković 2009).

The general situation in the majority of countries is still deteriorating, despite the success in the reduction of certain types of air pollution. During 2014 the air in the Belgrade region was moderately polluted, while on the territory of the city of Valjevo, in Western Serbia, the air was highly polluted. The sewerage system covers $48 \%$ of the population of the Republic of Serbia, with huge variations in the coverage between the districts, as well as between the urban and rural population. The largest cities of Belgrade, Novi Sad, and Niš release their wastewater untreated into the rivers. The loss of water in the water supply system in Serbia has a negative trend. On the other hand, the geographical position of the country, the variety of climate conditions and the situation in habitats create a rich biodiversity.

The concept of sustainable development is a new notion, particularly in Serbia. It is a multidisciplinary concept that includes economics, ecology, ethics, sociology, law, and is rounded up by politics. It relates to the harmonization of the economic, social and 
ecological dimension of development, i.e. the harmonization of production with nature in a way that would not lead to its being endangered. It links the welfare of the present and future generations with the capacities and limitations of the biosphere with the aim of making life on Earth sustainable (Obradović, Stanković i Obradović 2007). The positive side of this concept is that it appreciates the diversity of actual societies including the differences in their political and economic systems, different development goals of certain societies, as well as the specificities of local conditions and important safety aspects (Miladinović 2012).

Globalization is the process of economic, social, cultural and political activity that transcends the borders of nation states. On the one hand, this process offers the opportunity to advance, while on the other, it creates the danger of differentiation, increasing poverty and the subordinate position of undeveloped countries in the world of ever-growing interdependence. Globalization negatively affects the environmental quality in all countries, primarily the underdeveloped ones. However, what is certain is that globalization is an indisputable fact. It cannot be removed, avoided or neglected. It should be accepted and directed and shaped for the better (Karlić, 2008). Globalization also contributes to the strengthening of supranational institutions, which is very important for environmental protection and sustainable development, since ecological problems transcend national borders, and can be solved only through joint ventures at the global level. The development of technology, particularly information technology, which connects completely different societies through space and time, offers the possibility of the rapid spreading of information, including information on the endangerment of the environment, which could positively affect the development of environmental awareness and environmental culture (Miltojević 2004a). Serbia cannot certainly measure up to other countries in every field, but what it can and, as Kuzmanović (2012) states, must do, is to turn globalization into its instrument of development and progress.

\section{REFERENCES}

Biočanin, Rade. "Ekološka bezbjednost u uslovima zastrašujuće globalizacije i održivog razvoja.” Paper presented at the workshop "Innovation in engineering design". Rijeka, 27-28. January 2011.

Bjelajac, Željko, Dragan Dašić i Milovan Spasović. "Ekološka politika EU i njen krivično - pravni okvir." $M P$ 63, 4 (2001): 567-582. Accessed November 24, 2014. Doi: 10.2298/MEDJP1104567B

Bossel, Hartmut. Indicators for Sustainable Development: Theory, Method, Applications. A Report to the Balaton Group. Canada: International Institute for Sustainable Development, 1999. Accessed January 16, 2015. http://publ.ext.zalf.de/web/lsa_ergebnisse_agstruk_indikatoren/pdfs\%5Cbalatonreport.pdf

Crafts, Nicholas. "Globalisation and Economic Growth: A Historical Perspective". World Economy 27, 1 (2004): 45-58. Doi:10.1111/j.1467-9701.2004. 00587.x

Dinić, Jelena. Stavovi studenata Univerziteta u Nišu prema procesu odliva mozgova (graduate thesis). University of Niš, 2011.

Drljača, Miroslav. "Koncept održivog razvoja i sustav upravljanja.” Kvalitet i izvrsnost 1, 1-2 (2012): 20-26. Accessed September 17, 2014. http://bib.irb.hr/datoteka/580157.Koncept_odrivog_razvoja_i_sustav_upravljanja.pdf

Đurić, Jelena. "Ekološki aspekti globalizacije.” Institut za filozofiju i društvu teoriju 14 (1998): 45-60.

Ehrenfeld, David. "Globalisation: Effects on Biodiversity, Environment and Society." Conservation and Society 1, 1 (2003): 99-111. Accssed November 23, 2013 http://www.conservationandsociety.org/text.asp? 2003/1/1/99/49362

Enviromental Sustainability Index Report. 2005. Accssed November 19, 2014. http://sedac.ciesin.columbia.edu/ es/esi/ESI2005.pdf

Esty, C. Daniel, Mare Levy, Tanja Srebotnjak and Alex Sherbinin. 2005 Environmental Sustainability Index: Benchmarking National Environmental Stewardship. New Haven: Yale Center for Environmental Law \& Policy, 2005. Accessed July 12, 2017. http://earth.columbia.edu/news/2005/images/ESI2005_policysummary.pdf 
Hsu, Angel, Jay Emerson, Mark Levy, Alex Sherbinin, Laura Johnson, Omar Malik, Jason Schwartz and Malanding Jaiteh. The 2014 Environmental Performance Index, Full Report and Analysis. New Haven, CT: Yale Center for Environmental Law \& Policy, Columbia University, 2014. Accessed March 30, 2015. http://archive.epi.yale.edu/files/2014_epi_report.pdf

Janković Milić, Vesna, Sonja Jovanović i Bojan Krstić. "Analiza ekološke dimenzije održivog razvoja zemalja jugoistočne evrope na osnovu EPI metodologije.” Teme 36, 2 (2012): 461-481

Kanjevac Milovanović, Katarina, Jovan Milivojević, Aleksandra Kokić Arsić. "Metode za vrednovanje i monitoring kvaliteta životne sredine." Paper presented at the na National Confference, Kragujevac, May 10-12, 2006.

Karlić, Ivan. "Dvoznačnost fenomena globalizacije. Za globalizaciju solidarnosti." Filozofska istraživanja 113, 29-1 (2008): 87-106.

Kuzmanović, Aleksandar. “Globalizacija - mogućnosti za Srbiju.” Pravno-ekonomski pogledi 3 (2012): 1-12.

Lakušić, Branislava, Branka Stevanović, Radiša Jančić and Dmitar Lakušić. "Habitat-related Adaptations in Morphology and Anatomy of Teucrium (Lamiaceae) Species from the Balkan Peninsula (Serbia and Montenegro)". Flora - Morphology, Distribution, Functional Ecology of Plants 205, 10 (2010): 633-646. Doi: 10.1016/j.flora.2010.04.018

Levett, Roger. "Sustainability Indicators: Integrating Quality of Life and Environmental Protection." Journal of Royal Statistical Society: Series A (Statistics in Society) 161, 3 (1998): 291-302. Accessed May 25, 2015. Doi: 10.1111/1467-985X.00109

Living Planet Report 2016, Technical Supplement: Ecological Footprint. Global Footprint Network, 2016. Accessed August 15, 2017. http://d2ouvy59p0dg6k.cloudfront.net/downloads/technical_supplement_ecological_footprint_ 2016.pdf

Lukas, Figge, Oebels Kay and Astrid Offermans. "The Effects of Globalization on Ecological Footprints: An Empirical Analysis.” Environment, Development and Sustainability 19, 3 (2017): 863-876. Accessed September 7, 2017. Doi: 10.1007/s10668-016-9769-8

Martens, Pim and Mohsin Raza. "Is Globalisation Sustainable?". Sustainability 2 (2010): 280-293. Accessed September 10, 2017. Doi:10.3390/su2010280

Mićunović, Gordana, Nataša Novaković i Goran Stefanović. "Globalizacija i njen negativni uticaj na zemlje u razvoju." International Scientific Conference-Synthesis (2015): 345-348. Accessed February 14, 2017. Doi: 10.15308/Synthesis-2015-345-348

Miladinović, Slobodan. "Pitanje ekološke održivosti populacionog rasta." Teme 2 (2012): 581-595.

Miltojević, Vesna. Ekološka kultura. Niš: Fakultet zaštite na radu, 2004a.

Miltojević, Vesna. "Ekološka kultura i procesi globalizacije.” U Regionalni razvoj i integracija Balkana u strukture EU-Balkanska raskršća i alternative, 499-503. Niš: Filozofski fakultet Univerziteta u Nišu, 2004b.

Milutinović, Slobodan. “Odnos održivosti i održivog razvoja.” Teme 2 (2012): 596-613.

Monaghan, Paul. Review of Globalization: A Basic Text by George Ritzer. Journal of Rural Social Sciences 26, 2 (2011): 144-146. Accessed June 11, 2017. http://journalofruralsocialsciences.org/pages/Articles/JRSS\%202011\% 2026/2/JRSS\%202011\%2026\%202\%20144-146.pdf

Muradian, Roldan. "Economic Globalisation and the Environment." International Society for Ecological Economics (2004): 1-11. Accessed June 17, 2017. https://www.researchgate.net/publication/241573949_Economic_ Globalisation_and_the_Environment

Nadić, Darko. "Održivi razvoj i principi održivog razvoja u strateškim dokumentima Republike Srbije." Godišnjak Fakulteta političkih nauka 5, 6 (2011): 213-224.

Nešković, Slobodan. "Globalizacija životne sredine i međunarodna saradnja u eko-bezbednosti." Paper presented at $1^{\text {st }}$ International Conference Ecological Safety in Post-Modern Enviroment. Banja Luka, July 26-27, 2009.

Obradović, Miodrag, Dragica Stanković i Snežana Obradović. "Sklad ekologije i održivog razvoja." Šumarstvo 1-2 (2007). Accessed July 16, 2016. http://www.srpskosumarskoudruzenje.org.rs/index.php?option=com_content\& task=view\&id=43\&Itemid=30

Pajvančić-Cizelj, Ana. Koncept globalnog grada kao pristup razumevanju savremenih obrazaca urbanizacije $i$ globalizacije (doktorska disertacija). Novi Sad, Univerzitet u Novom Sadu, 2015.

Pavić-Rogošić, Lidija. Novi izazovi: Globalni ciljevi održivog razvoja do 2030. Održivi razvoj zajednice. Zagreb: ODRAZ, 2015.

Pečujlić, Miroslav. Globalizacija - dva lika sveta. Beograd: Gutenbergova galaksija, 2002

Pešić, Radmilo. Ekonomija prirodnih resursa i životne sredine. Beograd: Faculty of Agriculture, 2002.

Popović, Tihomir. "Kvalitet vazduha u Srbiji - od monitoringa do ocene." Paper presented at Confference "EU and Serbia at Work/EU i Srbija na delu". Beograd, March 17, 2015. Accessed August 15, 2017. http://www.sepa.gov.rs/download/prezentacije/2015/SEPA_EU_Fair_AIR_2015.pdf

Pavlović, Vukašin. Univerzitet i održivi razvoj. Beograd: FPN, 2011. 
Romančikova, Eva and Jana Mikocziova. "Environmental Aspects of the Globalization Process." Review of Applied Socio-Economic Research 2 (2011): 139-148. Accessed September 3, 2016. ftp://ftp.repec.org/ opt/ReDIF/RePEc/rse/wpaper/19Rev2_17_Romancikova.pdf

Srebrenkoska, Vineta, Midhat Jašić, Slobodan Sokolović and Ramzija Cvrk. "Environmental Sustainability and Industry." In Sustainable Technologies, edited by Zoltan Zavargo, 55-72. Novi Sad: University of Novi Sad, 2013.

Statistical Yearbook of the Republic of Serbia 2015. Belgrade: Statistical Office of the Republic of Serbia, 2015. Accessed October 15, 2016 http://webrzs.stat.gov.rs/WebSite/repository/documents/00/01/88/51/ Statisticki_godisnjak_Srbije_2015.pdf

Stojaković, Aleksandar. Ekološka svjest $i$ održivi razvoj. Paper presented at $1^{\text {st }}$ International Coference of Ecological safety in post-modern environment. Banja Luka, July 26-27, 2009.

Štrbac, Nada, Milovan Vuković, Danijela Voza i Miroslav Sokić. "Održivi razvoj i zaštita životne sredine." Reciklaža i održivi razvoj 5, 1 (2012): 18-29.

UN. The Millennium Development Goals Report. New York: UNIDP, 2007. Accessed July 19, 2017. http://www.un.org/millenniumgoals/pdf/mdg2007.pdf

UN. World Commission on Environment and Development Report: Our Common Future. Oxford: Oxford University press, 1987. Accessed July 7, 2017. http://www.un-documents.net/our-common-future.pdf

Van Veen-Groot, Danielle and Peter. B. Nijkamp. "Globalisation, Transport and the Environment: New Perspectives for Ecological Economics.” Ecological Economics 31, 3 (1999): 331-346. Accessed May 23, 2015. Doi: 10.1016/S0921-8009(99)00099-3

Veljković, Nebojša. “Indikatori održivog razvoja: Srbija i svet.” Accessed April 12, 2015. http://indicator.sepa. gov.rs/o-indikatori

Veljković, Nebojša. "Praćenje održivog razvoja u Srbiji." Beograd: Agencija za zaštitu životne sredine, 2011. Accessed April 11, 2015. www.sepa.gov.rs/download/odrziviRazvoj/odrziviRazvojSrbija.pdf

Vlada RS. Akcioni plan za sprovođenje strategije održivog razvoja Republike Srbije za period od 2009. do 2017 godine. Beograd: Službeni glasnik 57/08, 2008.

Vlada RS. Akcioni plan za sprovođenje strategije održivog razvoja Republike Srbije za period od 2009. do 2017 godine-izmena. Beograd: Službeni glasnik 31/10, 2010.

Vlada RS. Izveštaj o stanju zemljišta u Republici Srbiji za 2011. godinu. Beograd: Agencija za zaštitu životne sredine, 2012. Accessed May 19, 2015. http://www.sepa.gov.rs/download/Zemljiste_2011.pdf

Vlada RS. Nacionalna strategija održivog razvoja RS 2008. Beograd: Službeni glasnik RS 55/05, 71/05correction\&101/07, 2005/2007.

Vlada RS. Pravilnik o proglašenju i zaštiti strogo zaštićenih i zaštićenih divljih vrsta biljaka, životinja i gljiva. Beograd: Službeni glasnik RS 5/2010\&47/2011, 2010/2011.

Vlada RS. Zakon o zaštiti prirode. Beograd: Službeni glasnik RS 36/2009, 88/2010\&91/2010, 2009/2010.

Vranješ, Nevenko. "Globalni aspekti ekološke bezbjednosti." Paper presented at $1^{\text {st }}$ International Conference Ecological Safety in Post-Modern Enviroment, Banja Luka, July 26-27, 2009.

Waller-Hunter, Joke and Tom Jones. "Globalisation and Sustainable Development." International Review for Enviromental Strategies 3, 1 (2002): 53-62.

Wu, Pei-Ing, Liou Je-Liang and Su Ming-Ta. "Examination of the Diverse Views of Sustainable Development: An Approach to Monetize the Environment, Economy, and Society." Environmental Economics (openaccess) 5, 1 (2014): 62-75. Accessed June 28, 2017. https://businessperspectives.org/journals/ environmental-economics/issue-222/examination-of-the-diverse-views-of-sustainable-development-anapproach-to-monetize-the-environment-economy-and-society

Žužek, Marija. "Mogućnosti realizacije strategije održivog razvoja Republike Srbije." Paper presented at $1^{\text {st }}$ International Coference of Ecological safety in post-modern environment, Banja Luka, July 26-27, 2009. 


\section{KONCEPT EKOLOŠKE ODRŽIVOSTI I KRATAK OSVRT NA POKUŠAJE NJEGOVE PRIMENE U SRBIJI}

Osnovu napretka savremenog društva čini razvoj nauke i tehnologije, što je intenzivirano procesima globalizacije.Težnja za sve većim progresom, sve većom proizvodnjom kako bi se poboljšali uslovi života ljudi stvorili su i štetne posledice koje se ogledaju u ekološkoj krizi, odnosno narušavanju ekološke ravnoteže. U težnji za pronalaženjem rešenja nastao je model održivog razvoja u čijoj je osnovi usaglašavanje ekonomskih potreba sa očuvanjem ekološke ravnoteže na globalnom nivou, ali i lokalnom nivou.Zdrava i kvalitetna životna sredina ne samo da je osnovni uslov ekonomskog bogatstva, već su čist vazduh, zdrava voda i zdravo zemljište, te hrana osnovni preduslovi za dobro zdravlje ljudi.

Koncept održivog razvoja je relativno nov pojam, posebno u Srbiji. Međutim, on nije dovoljno razvijan niti sprovođen $u$ našoj zemlji. Razlozi za ovakvo stanje su mnogobrojni, među kojima svakako značajno mesto zauzima nezavidna ekonomska situacija, ali i činjenica da koncept održivog razvoja još uvek ne predstavlja široko prihvaćenu paradigmu razvoja u Srbiji. Za Srbiju, kao zemlje u razvoju, posebno je značajno očuvati ekološku ravnotežu i obezbediti održivi razvoj što je ostvarivo između ostalog i kroz međunarodnu saradnju u sferi zaštite životne sredine.

Ključne reči: životna sredina, ekološka kriza, održivi razvoj, Srbija. 